\title{
Study of the protective effect of Nigella sativa against Cimetidine induced reproductive toxicity in male mice
}

\author{
K. G. Ch. Al-Nailey
}

Coll.Vet. Med. /UniveAl-Qadisiya

\begin{abstract}
The present study was designed to investigate some histopathological changes produced by cimetidine on male reproductive organs (testes \& epididymis) in mice and extended to examine wherethere using of aqueous suspension of powdered Nigella sativa seeds have ability to reduce this toxicity.Forty male mice were divided into 4 groups. The first group received $25 \mathrm{mg} / \mathrm{kg} \mathrm{B.W}$. of cimetidine orally once daily. The second group drenched aqueous suspension of Nigella sativa at dose of $1000 \mathrm{mg} / \mathrm{kg} \mathrm{B.W}$. and then received cimetidine. While the third group drenched Nigella sativa aqueous suspension once daily, while fourth group (control group) received normal saline only and the study was continued for (76 days). Animals which were treated with cimetidine only along the period of experiment showed sever pathological changes, particularly in testes and epididymis, whereas oral administration of the aqueous suspension of Nigella seeds aqueous suspension significantly reduced these changes which reflected by obvious increment of spermatogonia and reducing the damage of seminiferous tubules. The protective activity of Nigella sativa has been resumed via diminishing the reproductive histopathological changes associated with long-term of treatment with cimetidine.
\end{abstract}

\section{Introduction}

Cimetidine ( Tagamet $\AA$ ) is a drug historically used to reduce gastric acid secretion. Published research dating back more than 20 years shows that this drug might make a greater impact in medicine if used as a cancer therapy rather than as a treatment for gastric disorders(1).It is an histaminic (H2) receptor antagonist, extensively prescribed for ulcers and now available without prescription. It is a competitive binds to these receptors in parietal cells and doesn't allow histamine to bind them. Histamine is responsible for signaling these cells to secrete acid. If cimetidine is present, the cells don't get the signal to produce acid thus reducing the $\mathrm{pH}$ of the stomach(2). Cimetidine is a drug widely use in human (3) and animals (4). It used in the treatment of ulcer which considered as important chronic disease and it's treatment required long period, may be it's continue along the life. So the using of this drug for long period, caused a major side effects such as gynecomastica, reduction in sperm count and reversible impotence in males (5). The review of published articles showed that there is increasing interest for decreasing side effects which usually associated with chronic administration of drugs as in longterm treatment of ulcer with cimetidine. For that purpose using of herbs has been gained importance to diminish drug toxicity.One of the most herbs which was used in treatment of diseases \& diminishing of toxication was Nigella sativa which has substantial historical in tradition medicine. It has the ability to significantly over coming illness or maintaining health if taken over the time, and it act on the principle of assisting the body's own natural healing process (6). It is well known traditionally and publically plants in general and Nigella sativa in particular are taken or prescribed for patients in the form of tea i.e. the powder of the seeds is macerated or simply boiled to prepare a remedy (7).On the viewing of medicinal properties of cimetidine and Nigella sativa this study designed to:

1- investigate the cimetidine toxicity on male reproductive system in mice.

2- Find the effectiveness of using Nigella sativa seeds suspension to diminish a reproductive toxicity which caused by long-term treatment of cimetidine. 


\section{Materials and Methods}

The present study was conducted on (40) white male mice of approximately the same age (6 weeks) and body weight (25$31 \mathrm{gm})$. The animals were housed in a $6 \times$ $4 \times 3 \mathrm{~m}^{3}$ room in animal house of Vet. Medicine College/ Al-Qadisyia University under 12 hours light / 12 hours dark at $28 \pm$ $2{ }^{\circ} \mathrm{C}$ and put as 5 mice in each standard plastic cages and this study continued for 76 days.Drug preparation: Five hundredmilligram of pure cimetidine (provided by SDI, Iraq) were dissolved in $(200 \mathrm{ml})$ of distilled water to obtain stock solution included $0.25 \%$ cimetidine. The a volume of $0.1 \mathrm{ml} / 10 \mathrm{gm} \mathrm{B.W}$, with a maximum volume of $0.3 \mathrm{ml} /$ mouse, from stock solution was administered orally by using of stomach tube.Plant material preparation: To (15) gm of Nigella sativa seeds, $100 \mathrm{ml}$ of distilled water were added, mixed and ground by a blender, this was made for 5-6 intervals, 60 seconds each time, 60 seconds apart, at room temperature until complete grinding and mixing to obtain a stock solution of crude suspension (7).

\section{Experimental Design:}

\section{Results \& Discussion}

The present study demonstrated that cimetidine considered as testicular toxicant to male reproductive system of mice due to major histopathological changes which showed in testes and epididymus. The animals of first group (animals received cimetidine) showed sever microscopic changes in testes \& epididymus. The testes showed suppression of spermatogenesis which resulting in oligospermia (reduced number of sperms), it was reported by (10), they reported that oligospermia may be occur due to long treatment of cimetidine. Also the results in this group demonstrated sever vaculation of spermatogonia due to degenerative process of seminifrous tubules (figure 1) \& (figure 2) and this reported by (11), they indicate that there is debilitating in seminifrous tubules due to taking high doses of cimetidine. Also in the present study, the testes in animals of first group showed presence of spermatid multinucleated giant cells (figure 3), they
Mice were randomly divided into 4 equal groups, ten animals for each group:

First group: Administered orally with Cimetidine at a dose $25 \mathrm{mg} / \mathrm{kg}$ once a daily(8).

Second group: Administered with watery suspension of drenched Nigella sativa seeds at a dose $(1000 \mathrm{mg} / \mathrm{kg}$ B.W. P.O (orally)) based on previous study (7), and 60 minute later treated with $25 \mathrm{mg} / \mathrm{kg}$ B.W. P.O. of cimetidine.

Third group: Administered orally with $1000 \mathrm{mg} / \mathrm{kg} \mathrm{B.W}$. P.O. of Nigella sativa aqueous suspension only.

Fourth group: Treated orally with normal saline only and serve as a control group. For histopathology, pieces of 1-2 cm 3 from testes and epididymus were taken then kept in $10 \%$ neutral buffered formalin for fixation, processed routinely in histokinette, cut at $5 \mathrm{Mm}$ thickness by microtome (Jung 4291, West Germany) and stained with Haematoxylin and Eosin stain then examined under light microscope (9).

are special cells indicate the degenerative process which occurring in seminiferous tubules. This result proved by (12), they note presence of spermatid multinucleated giant cells in testes of rat due to long-term treatment of cimetidine. Epididymal tubules of this group were demonstrated empty and not contain sperms (figure 4) \& (figure 5) due to inhibition of production of sperms (spermatogenesis) in the testes because epididymus is the pathway of the sperms to outside from the testes.In second group (animals drenched Nigella sativa and then received cimetidine), the toxicological changes were less than previous group. In testes, there is mild suppression of spermatogenesis and mild vaculation of spermatogonia and spermatozoa present in large numbers more than first group, (figure 6), also there was no presence of spermatid multinucleated giant cells. So some epididymal tubules contain few sperms and 
others were filled (figure 7) (figure 8). Reducing of these toxicities occurs due to activity of Nigella sativa seeds which ameliorate or protect the reproductive organs from toxic effect which produced by long-term of treatment of cimetidine, cimetidine binds to androgen receptors (13), and antiandrogenic effects such as gynecomastasis (in men) and galactorrhea (in women) have been reported. In addition, a reduction in sperm count and reversible impotence have been reported in male patients receiving long-term treatment for hypersecrtory states (5), these effects are rarely observed with therapy that continues for no longer than 8 weeks. Nigella sativa opposes the antiandrogenic effect of cimetidine might possibly via a mechanism such as stimulation of leydig's cells in testes due to effect of Nigella sativa seeds on action of coenzymes in metabolic pathways and production of steroid hormones. Also there is another mechanism of Nigella sativa, it can produce testosterone hormone by conversion of cholesterol molecule into pregnenolone and then into testosterone hormone (14).However, microscopic examination of section of testes or epididymus, from animals treated only with watery suspension of Nigella sativa seeds showed no much difference from that sections from control group (figure9), (figure 10) \& (figure 11) .

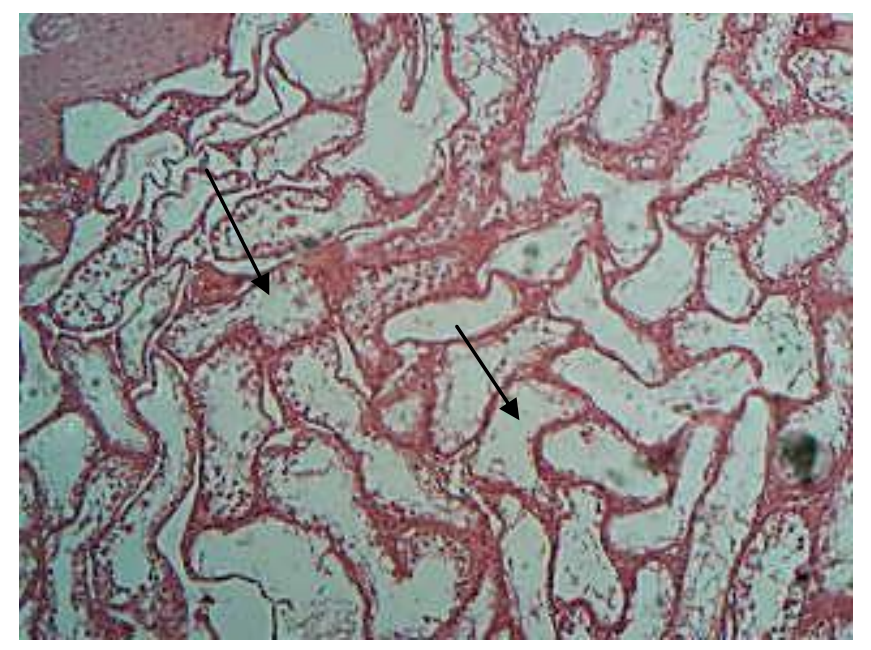

Figure (1): Testis. (first group), note sever degeneration of seminiferous tubules (arrows), vacuolation of spermatogonia and reduced number of spermatozoa, 10X H\&E.

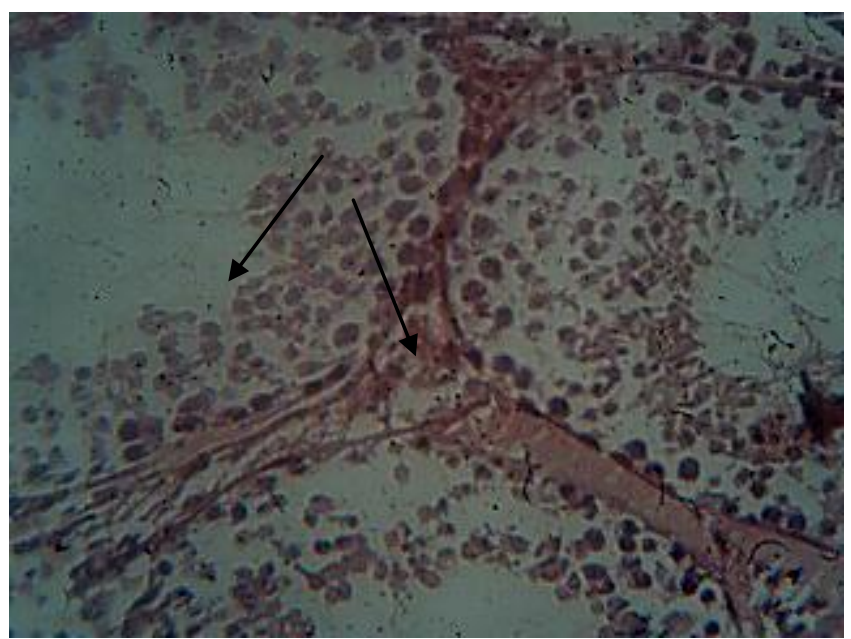

Figure (2): Testis. (first group), note sever degeneration of seminiferous tubules, vaculation of spermatogonia (arrows) and reduced number of spermatozoa. 40X H\&E. 


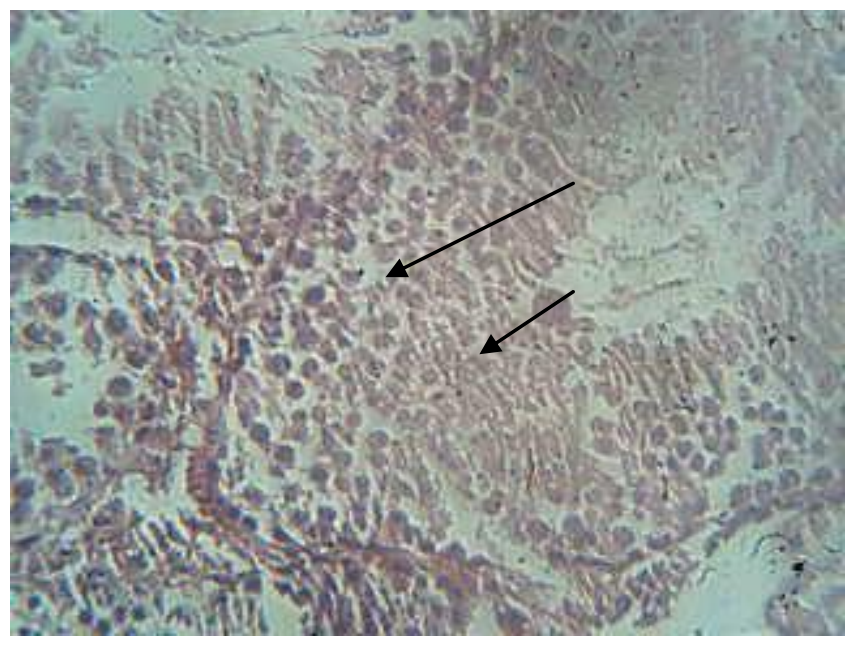

Figure (3): Testis. (first group), note sever degeneration of seminifrous tubules, and presence of spermatid multinucleated giant cell (arrow). 40X H\&E.

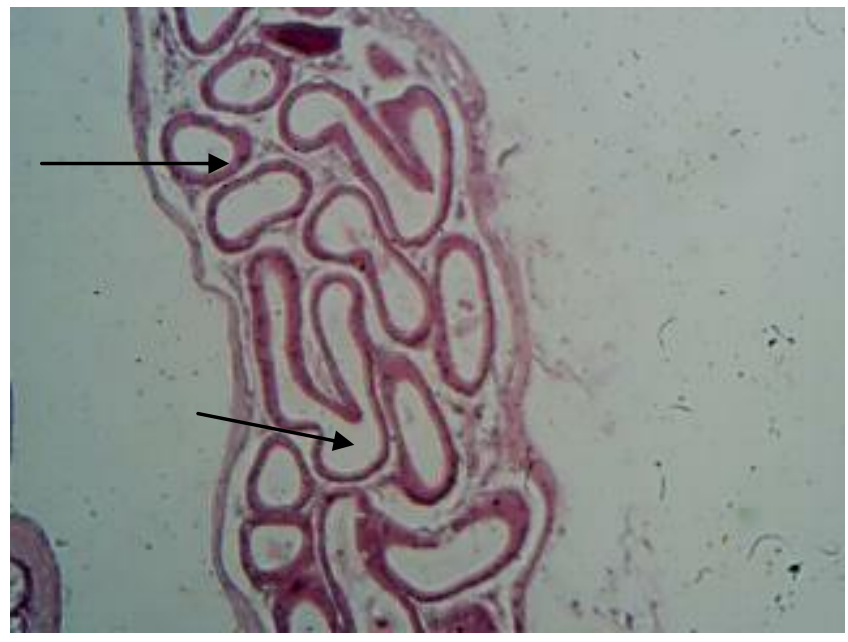

Figure (4): Epididymus. (first group), note epididymal tubules were empty from sperms (arrows). 10X H\&E.

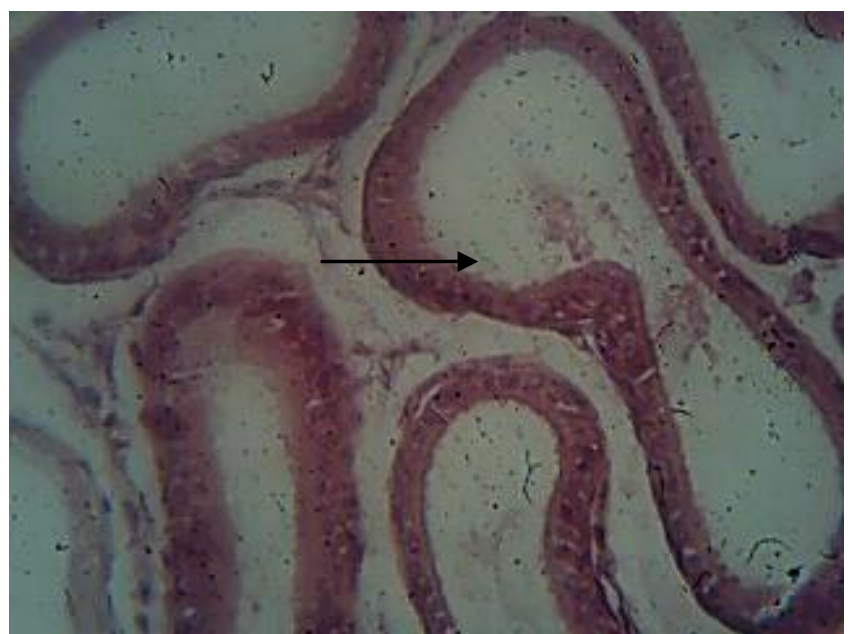

Figure (5): Epididymis. (first group), note epididymal tubules were empty from sperms (arrow). 40X H\&E. 


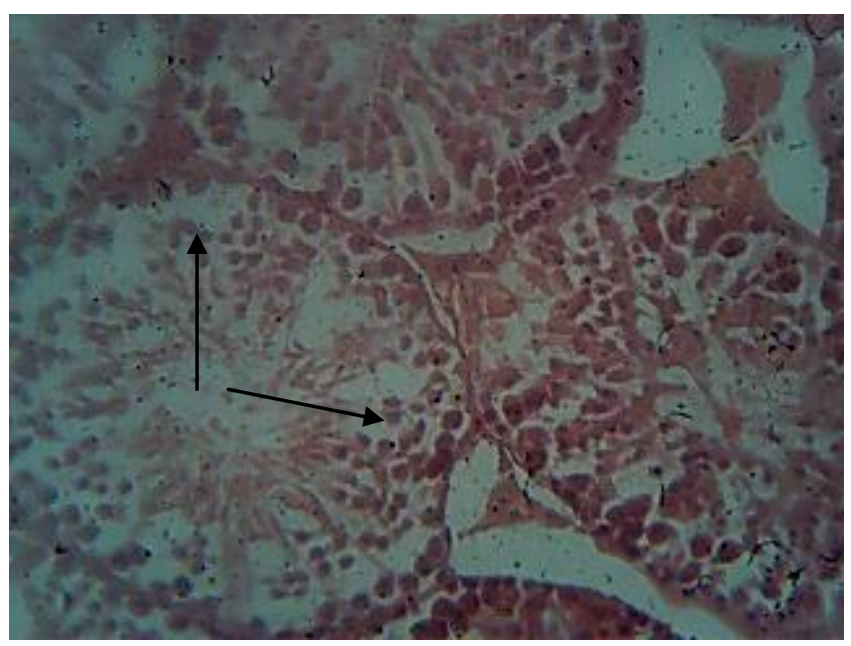

Figure (6): Testis. (second group), there is mild degeneration of seminiferous tubules with mild vacuolation of spermatogonia (arrows). 40X H\&E

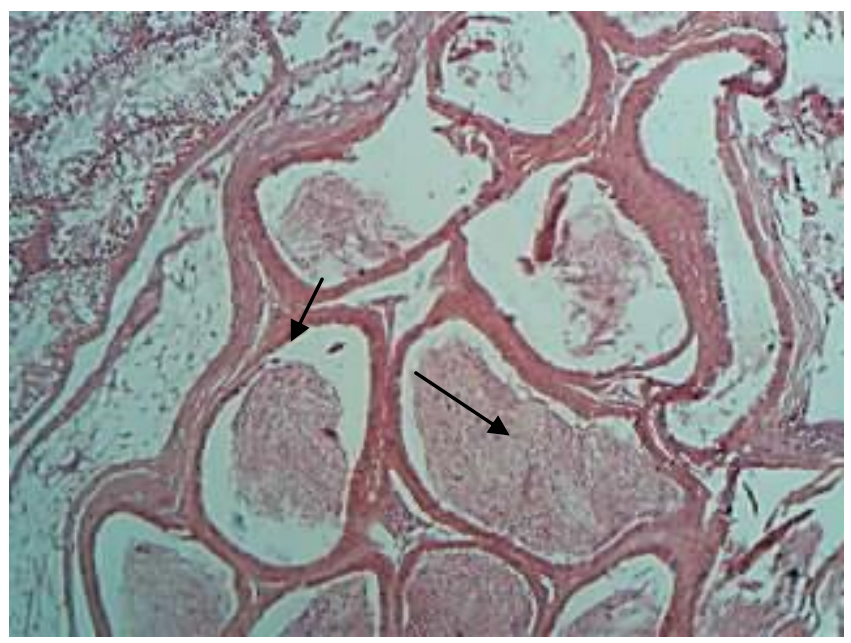

Figure (7): Epididymis. (second group), note some epididymal tubules contain few sperms (arrows) and the others were filled. 20X H\&E.

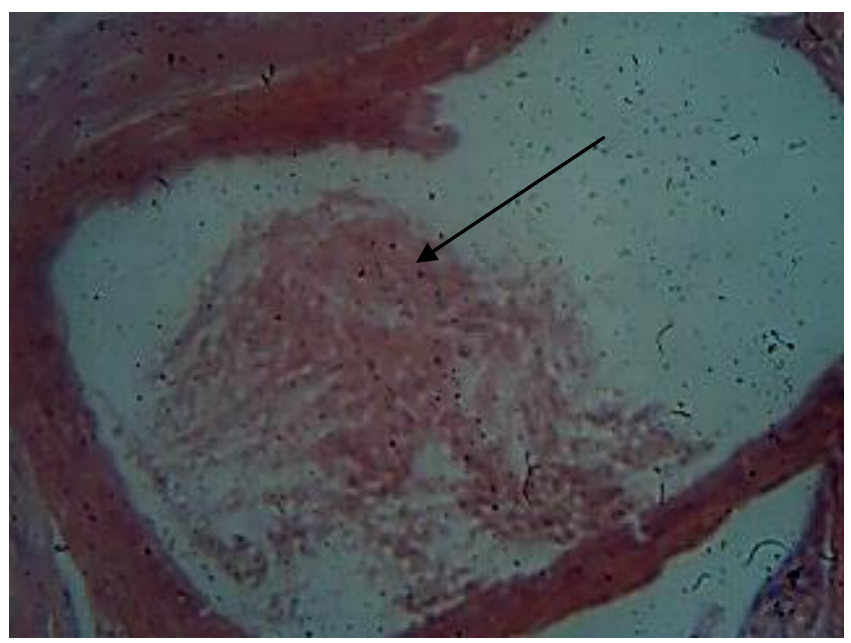

Figure (8): Epididymis. (second group), note one epididymal tubule contains few sperms (arrow). 40X H\&E. 


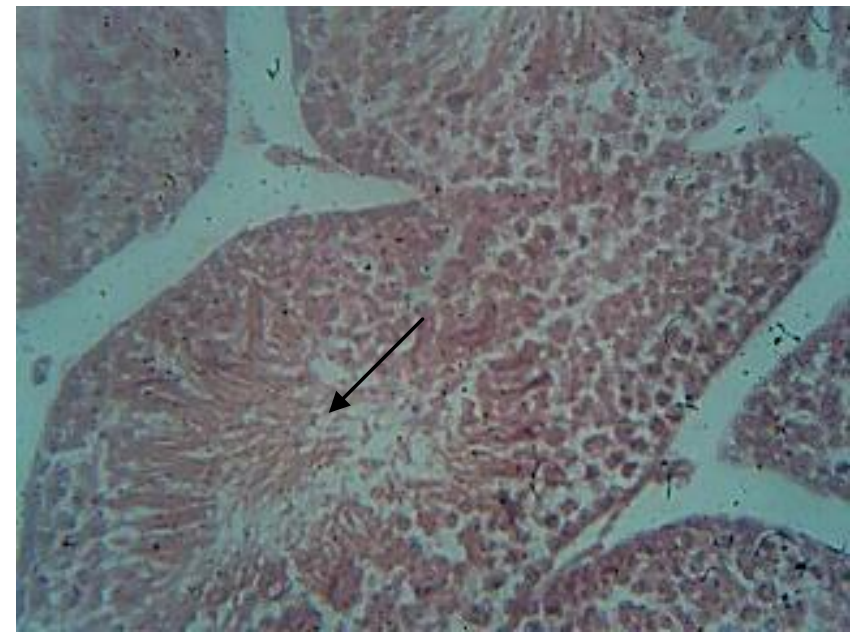

Figure (9): Testis. (third group), there is normal seminiferous tubules and normal spermatogenesis (arrow). 40X H\&E.

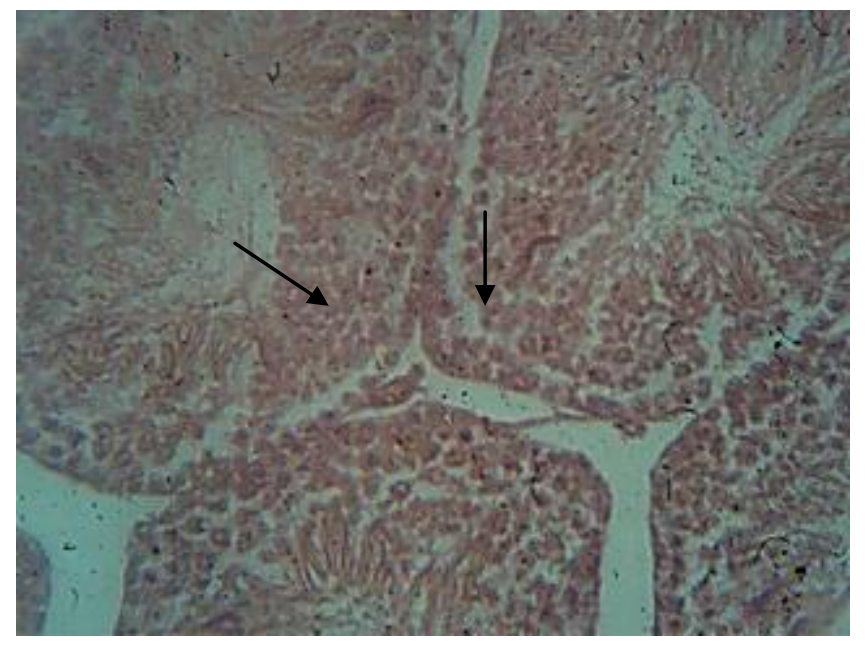

Figure (10): Testis. (Fourth or control group), there is normal seminiferous tubules and normal spermatogenesis. 40X H\&E.

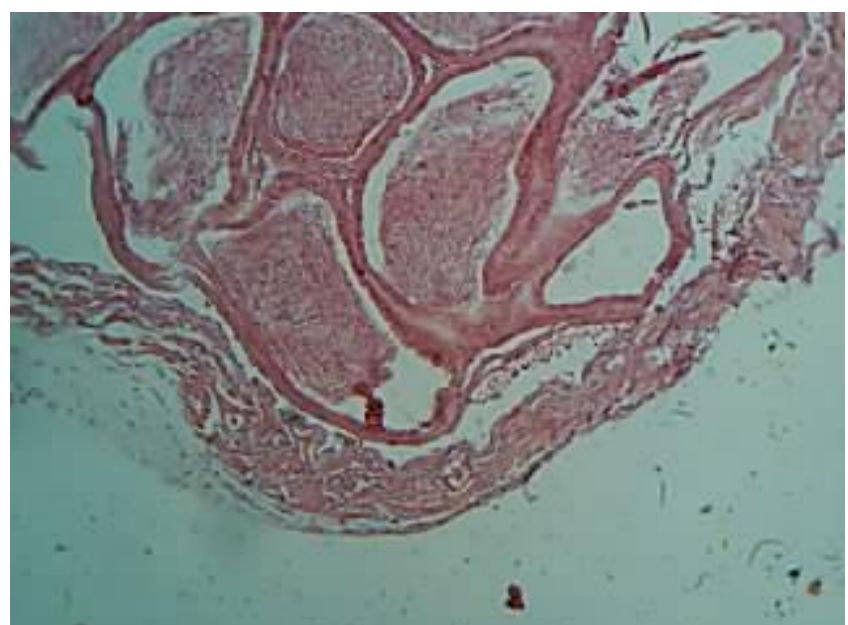

Figure (11): Epididymis. (fourth or control group) note epididymal tubules filled with sperms (arrows). 10X H\&E. 


\section{References}

1.Porro G.B.; Cheli R.; Dobrilla G.; Verme G.; Molinari F.; Pera A.; Petrillo M. and Valentini M. (1978). Treatment of Active uodenal Ulcer with Oral Cimetidine: a Multicenter Controlled Endoscopic Trial. Digestion; 17: 383- 386.

2.Luiz R. F. , Marcelo C. Leal, Estela S. C., Anilton V., Luciano D. and Lonnie D. R. (2009). Cimetidine (Tagamet) Is a Reproductive Toxicant in Male Rats Affecting Peritubular Cells. Online ISSN: 1529-7268

3.Morgan A. G., McAdam W. A., Pacsoo C, Walker B E, and Simmons A V . (1978). Cimetidine: an advance in gastric ulcer treatment? Br Med J. 11; 2(6148): 1323-1326.

4.Brimblecombe R.W., Leslie G.B., Walker T.F.(1985). Toxicology of Cimetidine. SAGE Journals Online. Human \& Experimental Toxicology, Vol. 4, No. 1, 13-25. 5.Sawyer D, Conner C.S., and Scalley R. (1981). Cimetidine: adverse reactions and acute toxicity. American Journal of Hospital Pharmacy, Vol. 38, Issue 2, 188197.

6.Ahmed Z, Ghafoor A, and Aslam M. (2004). Nigella sativa - A potential commodity in crop diversification traditionally used in healthcare Project on introduction of medicinal herbs and spices as crops, ministry of food, agriculture and livestock, Pakistan.

7.Al- Shebani W. H. (2005). Study of some pharmaceutical properties of watery suspension of Nigella sativa seeds. MSc. thesis. Vet. Med. College. Bagd. University. Iraq.

8.Festen H P, Berden J H, and Koene R A.(1980). Cimetidine does not accelerate skin graft rejection in mice. Clin Exp Immunol ; 40(1): 193-196.

9.Luna L.G.(1968). Manual of histologic staining methods of the armed force institute of pathology. $3^{\text {rd }}$ ed., McGraw Hillbook company, NY, Toronto. London, Sydney. P.P 12-31.

10. Wang C, Lai C, Lam $\mathrm{K}$, Yeung $\mathrm{K}$. (1982). Effect of cimetidine on gonadal function in man. $\mathrm{Br} \mathrm{J}$ Clin. Pharmacol.; 13:791-794.

11. Gill M, Sareen M, Sanyal S. (1991). Effect of H2-receptor antagonists, cimetidine and ranitidine on reproductive functions in male mice. Indian J Exp Biol; 29:900906.

12. Sasso C.; Giovanoni M. ; Hayashi H. \& Miraglla S.M. (2001). Morphological alterations and intratubular lipid inclusions as indicative of spermatogenic damage in cimetidine-treated rats.Archives of andrology. ISSN 0148.5016. Cod en Arandr, vol. 46, pp. 5-13.

13. Winters S, Banks J, Loriaux D. (1979). Cimetidine is and antiandrogen in the rat. Gastroenterology; 76: 504-509.

14. Al-Zamely H. A. (2008). Effect of Nigella sativa L. seeds on certain physiological properties and semen in male Awassi Sheep. PhD. Thesis. Vet. Med. College. Bagh. Univer. 


\section{دراسة التأثير الواقي للحبة السوداء ضد السمية التناسلية المتسببة بالسايمتدين في ذكور القئران \\ خليّل كزار جلاب النايلي لئي \\ كلية الطب البيطري/جامعة القادسية}

\section{الخلاصة}

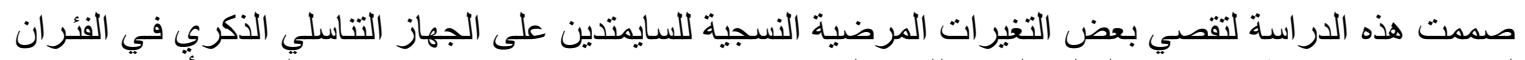

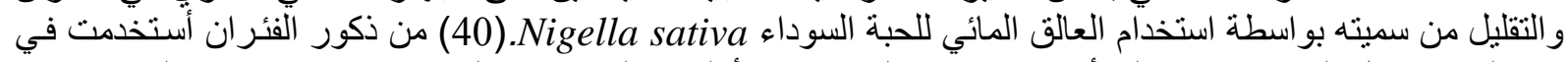

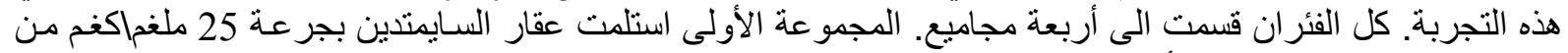

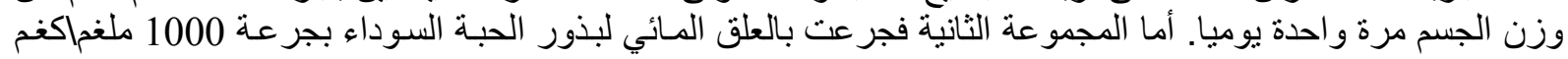

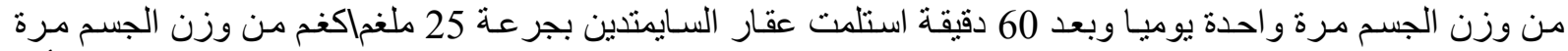

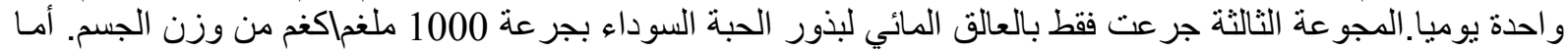

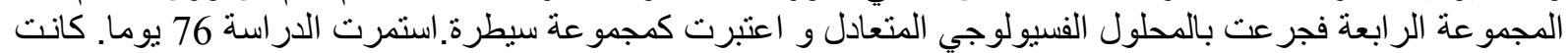

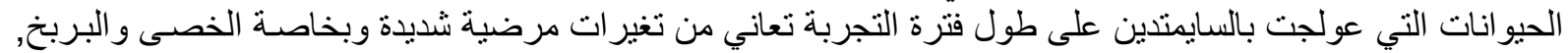

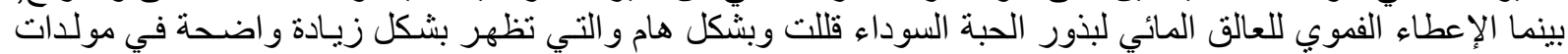

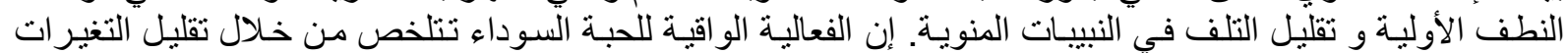
المرضية النسجية التناسلية والمقترنة بالمعالجة طويلة الأمد بالسايمتدين. 